\title{
Utilization of Adsorbent Carbon Coconut Shell for Purification of Used Cooking Oil
}

\author{
Siti Khuzaimah*, Norma Eralita \\ Chemical Engineering, Faculty of Industrial Engineering, Nahdlatul Ulama Al Ghazali University \\ * email : khuzaimahsiti86@gmail.com \\ DOI : 10.20885/ijca.vol3.iss2.art7
}

\section{ARTICLE INFO}

Received : 16 July 2020

Revised : 05 September 2020

Published : 09 September 2020

Keywords : Cooking Oil, Coconut

Shell, Activated Carbon, Acid

Number, Peroxide Number

\begin{abstract}
Cooking oil is one of the primary commodities people need to process food. Repeated use of cooking oil at high-temperature heating produces foul smell that reduces the quality and nutritional value of fried food. Decomposition consists of negative affects quality, but it also results in unfavorable flavor and reduced nutritional value of fried food. An alternative method to treat used cooking oil is adsorption with carbon made of coconut shells. This research aims to lower the levels of acid and peroxide numbers of used cooking oil by purifying it with activated carbon. The acid number determined using the acidimetric and alkalimetric titration method, while the peroxide number measured using the iodometric titration method. These two methods used to analyze samples of fresh cooking oil, used cooking oil, and used cooking oil treated with activated carbon. Results showed a decrease in acid number $34.1449 \%$ the second, $29.4103 \%$ the fourth use, and $37.5092 \%$ on the sixth use of cooking oil. Meanwhile, acidity reduced by $34.1508 \%$ the second use, $29.3883 \%$ the fourth use, and $37.5066 \%$ the sixth use of cooking oil. It found that peroxide number experienced a decrease in $81.2836 \%$ the second use, $85.3674 \%$ the fourth use, and $62.2462 \%$ the sixth use of purified cooking oil.
\end{abstract}

\section{INTRODUCTION}

Cooking oil one of the so-called nine basic needs people consume in Indonesia. It is an essential refined vegetable oil that can use to process food. Other than its main function to fry, it adds flavor and helps to provide texture in baking [1]. Cooking oil is one of the basic needs of people using continuously and repeat there a high temperature that will cause discoloration [2].

Good cooking oil has heat resistant properties, doesn't damage fried products, produces products with good texture and taste, has little smoke after repeated use, and produces a golden color on the product [3]. Utilization of cooking oil for both industry and household will sure produce used cooking oil which still contains high levels of fatty acids [4]. Oil cooking or oil fry the former, is oil cooking waste that can be derived from the types of oil cooking as well as oil corn, oil vegetable, oil cumin, and so on. This oil is use oil and when viewed from its chemical composition contains carcinogenic compounds formed during the frying process and unsaturated fatty acids. So that the sustainable use of used cooking oil can damage health [5]. The growth in population and the development of industry, restaurants, and ready to eat food causes used cooking oil to produce in rather high quantities [6].

Cooking oil is one of the primary commodities people need to process food. Demand for cooking oil is ever increasing in line with population growth in Indonesia. This means that the amount of used cooking oil is increasing. Cooking oil consumption by some industries in Indonesia that use deep frying for food processing estimate \pm 182 thousand tons. Current $50 \%$ of used cooking oil from the deeply frying food industry dumped. An estimate suggests that the amount of used cooking oil in Indonesia is 19 tons [7].

The growing business deep-fried food comes an increasing volume of used cooking oil, which up until hasn't received much attention. approaching all fried food sellers continuously use cooking oil for multiple frying properly replacing it. Most of the time, they fair direct add much fresh cooking oil to it. Repeated use of cooking oil results in the decomposition of compounds making up cooking oil. Decomposition consists of negative affects quality, but it also results in unfavorable flavor and reduced nutritional value of fried food. Moreover, some components decomposition 
proves to detrimental to health as they cause damages, principal to organs responsible for oil metabolism. They can cause diarrhea, fat clogging in the blood vessel, and even cancer. But most notably, they reduce the digestibility of fat [8].

An alternative method available to treat used cooking oil is through purification using some adsorbents. First results from treatments using bentonite and activated carbon revealed that purified used cooking oil did have reduced acid and peroxide numbers, but they were still below Indonesian National Standard values. Some other research using activated carbon made of sugarcane bagasse showed that this type of activated carbon is still effective enough to purify used cooking oil as it doesn't adequately reduce the level of free fatty acid. Activated charcoal as a metal producer which influence by $\mathrm{pH}$ and carbon concentration ability to overcome environmental problems [9].

From research used seeds of Moringa oleifera to purify used cooking oil. Results from this foundation that the adsorbent was capable of reducing water content and specific weight that meets the Indonesian National Standard (SNI) criteria, but the 46\% reduction in peroxide content hasn't met the SNI requirements [10]. Another research using zeolite successful adsorbed free fatty acid that resulted in an acid number from purification at 1.71, which met the SNI requirements [11]. Another research using activated carbon made of risk husk has proven its efficacy in improving. Used cooking oil quality and reducing the risk of liver or kidney cell congestion, fine preventing the accumulation of fat droplets, either in the liver, the heart, or the artery [12].

In the meantime, activated carbon made of coconut shell is found to be very potent. At present, the consumption of activated carbon around the globe is at 300,000 tons/year. Of this figure, around $10.12 \%$ is activated carbon made of coconut shells. Activated carbon is used by all kinds of industries, including medicine, food, drinks, water treatment, and many more [13]. Research using coconut shell has successfully reduced water content and has come closest to the quality threshold of $0.1 \mathrm{mg} / \mathrm{L}$. It was achieved at a treatment period of 60.25 minutes $(0.411 \mathrm{mg} / \mathrm{L})$ [14]. The free fatty acids for coconut oil are often expressed as\% lauric acid [15].

This research aims to term the proper treatment for used cooking oil produced by the fried food industry around Jl. Kalimantan in Cilacap District, Central Java using activated carbon made of coconut shell and to see whether the used cooking oil in this area still falls within the quality threshold set by the government.

This research found iodine number, acid number, and peroxide number and hence, conclude whether the used cooking oil in this area can still be used, according to the quality threshold set by the SNI. The use of activated carbon made of coconut shells is expected to lower the cost of treatment for used cooking oil that is to reduce its acid and peroxide number efficiently.

\section{METHOD}

\subsection{Material and Instrument}

The laboratory equipment used in this research is a burette, magnetic stirrer, Erlenmeyer flask, clamp, stand, volumetric flask, ball pipette, analytical balance, measuring cylinder, water bath, Liebig cooler, stirring bar, and filter. Whatman filter paper number 1 and 42 (vacuum) and some other glass instruments. Meanwhile, the materials used in this research are bulk cooking oil, used cooking oil, activated carbon, $\mathrm{KI}, \mathrm{KOH}$, phenolphthalein indicator, amylum indicator, sodium thiosulfate, chloroform, 95\% alcohol, $\mathrm{HCl}, \mathrm{K} 2 \mathrm{Cr} 2 \mathrm{O} 7$, and oxalate acid.

\subsection{Procedure}

\section{Sample preparation}

Samples of used cooking oil from 2, 4, and 6 times uses were taken from fried food sellers.

\section{Purification of used cooking oil}

An amount of $\pm 200 \mathrm{ml}$ used cooking oil was prepared and then filtered to get rid of food leftovers, before 10 gr of activated carbon was added. This mixture was then stirred for 30 minutes and further filtered using Whatman paper number 1, and then 42 .

\section{Preparation of reagents and standard solutions}

Solutions of $\mathrm{KOH}, \mathrm{Na}_{2} \mathrm{~S}_{2} \mathrm{O}_{3}$, phenolphthalein indicator and amylum indicator were also used, while oxalate acid and $\mathrm{K}_{2} \mathrm{Cr}_{2} \mathrm{O}_{7}$ were used as standards. 


\section{Quality test}

Quality test of fresh cooking oil. Quality test of cooking oil used for 2, 4, and 6 times frying. Quality test of cooking oil used for 2, 4, and 6 times frying after purification using activated carbon that meets SNI requirements. Quality test used acid and peroxide numbers as benchmark parameters as shown in Eq. 1 and Eq. 2

Measurement of acid number (the acidimetric and alkalimetric method). An amount of $10 \mathrm{~g}$ cooking oil was added with $50 \mathrm{ml}$ of $95 \%$ alcohol and heated for 10 minutes using a water bath, while continuously being stirred and refluxed. Alcohol plays the role of dissolving fatty acid. This mixture was then cooled down and titrated with $\mathrm{KOH} 0.1 \mathrm{~N}$ using PP indicator until a satisfactory pink color is obtained.

$$
\text { Acid Number }=\frac{m l \text { KOH } x \text { N KOH } x \text { BM KOH }}{\text { Mass }(\text { gram })}
$$

$$
\text { Acid Content }=\frac{263 \times \mathrm{N} \mathrm{KOH} \times \mathrm{BM} \mathrm{KOH}}{10 \times \text { Mass }(\text { gram })} \%
$$

Where:

$\mathrm{KOH} \mathrm{Ml}=$ number of $\mathrm{KOH}$ moles for titration

$\mathrm{KOH} \mathrm{N}=$ normality of $\mathrm{KOH}$ solution

$\mathrm{KOH} \mathrm{MW}=$ molecular weight of $\mathrm{KOH}(56.1)$

Sample Weight: weight of the sample (gr)

263 = molecular weight of fatty acid in coconut oil.

Measurement of peroxide number (the iodometric method). An amount of 5 grams of oil was added with $30 \mathrm{ml}$ of a solvent consisting of $60 \%$ glacial acetate acid and $40 \%$ chloroform. Once the oil was dissolved, $0.5 \mathrm{ml}$ of $\mathrm{KI}$ solvent was added and stirred. Two minutes later, $30 \mathrm{ml}$ of water was also added to allow the release of iodine (I2). Free iodine was then titrated using sodium thiosulfate using an amylum indicator until the color blue disappeared. The value is determined by Eq. 3

$$
\text { Number Peroksida }=\frac{(t s-t b) \times N \text { Na2S203 } \times 1000}{\text { Mass }(\text { gram })}
$$

Where:

Ts = amount of $\mathrm{Na}_{2} \mathrm{~S}_{2} \mathrm{O}_{3}$ solvent in $\mathrm{ml}$ for sample titration

$\mathrm{Tb}=$ amount of $\mathrm{Na}_{2} \mathrm{~S}_{2} \mathrm{O}_{3}$ solvent in $\mathrm{ml}$ for paper titration

$\mathrm{Na}_{2} \mathrm{~S}_{2} \mathrm{O}_{3} \mathrm{~N}=$ normality of $\mathrm{Na}_{2} \mathrm{~S}_{2} \mathrm{O}_{3}$

\section{Frying Process}

The oil used in this research is bulk cooking oil made of palm oil. Initial frying used $4 \mathrm{~kg}$ of fresh cooking oil to fry tofu and then banana for 15 minutes. An amount of $500 \mathrm{gr}$ of this was then taken as a sample of 2-time frying oil. The remaining oil was cooled down for 4 hours and was then used again to fry banana and then fritter for another 15 minutes. Yet another $500 \mathrm{gr}$ of this was taken as a sample of 4-time frying oil. The remaining oil was again cooled down and was then used again to fry banana and sweet potato for 15 minutes also. Another $500 \mathrm{gr}$ of this was taken as a sample of 6-time frying oil. The three collected samples were then treated for purification using activated carbon, as well as tested for their quality.

\section{Treatment of used cooking oil using activated carbon}

During purification with activated carbon, $200 \mathrm{ml}$ was taken from each sample of second, fourth, and sixth frying oil and put into Erlenmeyer flasks. Meanwhile, 50 gr of carbon was heated on a hot plate to activate and open its pores. Each sample of $200 \mathrm{ml}$ used cooking oil was then added with $10 \mathrm{gr}$ activated carbon each and stirred for 15 minutes. The next treatment was filtering using Whatman paper number 1 and 42. 


\section{RESULT AND DISCUSSION}

\section{a. Acid number test}

To calculate the acid number, $10 \mathrm{gr}$ was taken from each sample and was then added with $50 \mathrm{ml}$ of alcohol. This alcohol serves to dissolve fatty acid. Once cold, this sample was then titrated using $\mathrm{KOH} 0.1 \mathrm{~N}$ using the PP indicator until the pink color is obtained. Results of free fatty acid number calculation and measurement of the free fatty acid content of used cooking oil, both before and after treatment are given in the following Table 1 and Table 2.

TABLE 1. Acid number (mg KOH/gr) used cooking oil prior to treatment and after treatment

\begin{tabular}{lllll}
\hline Type of cooking oil & \multicolumn{4}{l}{ Time Frying } \\
\cline { 2 - 5 } & 0 & 2 & 4 & 6 \\
\hline Fresh cooking oil & 0.3569 & - & - & - \\
Used cooking oil prior to treatment & - & 2.0700 & 0.291 & 0.4039 \\
Used cooking oil after treatment & - & 1.3632 & 0.3029 & 0.2524 \\
Reduction in acid number & - & 0.7068 & 0.1263 & 0.1515 \\
\% reduction in acid number & - & 34.1449 & 29.410 & 37.50 \\
\hline
\end{tabular}

The acid number of 2-time frying coconut oil is more than the threshold set by SNI of 0.6 at most. The use of activated carbon is capable of reducing the acid number by $33.6881 \%$. The reduction of acid number in used cooking oil from 2-time frying amounts to 0.7068 , from 4-time frying amounts to 0.1263 , and from 6-time frying amounts to 0.1515 .

TABLE II. acid content (\%) of used cooking oil before and after treatment

\begin{tabular}{lllll}
\hline Type of cooking oil & \multicolumn{4}{l}{ Time Frying } \\
\cline { 2 - 5 } & 0 & 2 & 4 & 6 \\
\hline Fresh cooking oil & 0.1673 & - & - & - \\
Used cooking oil prior to treatment & - & 0.9704 & 0.2011 & 0.1893 \\
Used cooking oil after treatment & - & 0.6390 & 0.1420 & 0.1883 \\
Reduction in acid number & - & 0.3314 & 0.0591 & 0.0710 \\
\% reduction in acid number & - & 34.1508 & 29.3883 & 37.5066 \\
\hline
\end{tabular}

Free Fat content in 2-time frying cooking oil is at $0.9704 \%$, in 4-time frying is at $0.2011 \%$, and in 6-time frying is at $0.1893 \%$. The use of activated carbon has been able to lower fat content by $0.3314 \%$ in 2-time frying cooking oil, which meets the purification quality standard. In the meantime, purification of 4 and 6-time frying cooking oil has lowered fat content by $0.0591 \%$ and $0.0710 \%$, respectively. The average reduction in acid level with the use of activated carbon is at $33.6819 \%$.

Oxidation and hydrolysis of cooking oil are accelerated by heat and due to contact with the air. Hydrolysis itself is accelerated by water [16]. This research made use of cooking oil as samples. These samples are measured for acid number and peroxide number after use of up to three frying repetitions. Cooking oil samples were taken from fried food sellers. The Acidimetric and alkalimetric titration method is used to calculate the acid number and measure acid content. The results show that activated carbon can reduce the acid number and fatty fat acid content in used cooking oil. Free fatty acid content is calculated based on molecular weight as a percentage of palmitic acid. A comparison of the acid number and acid content before and after treatment is given in the following Figure 1. 


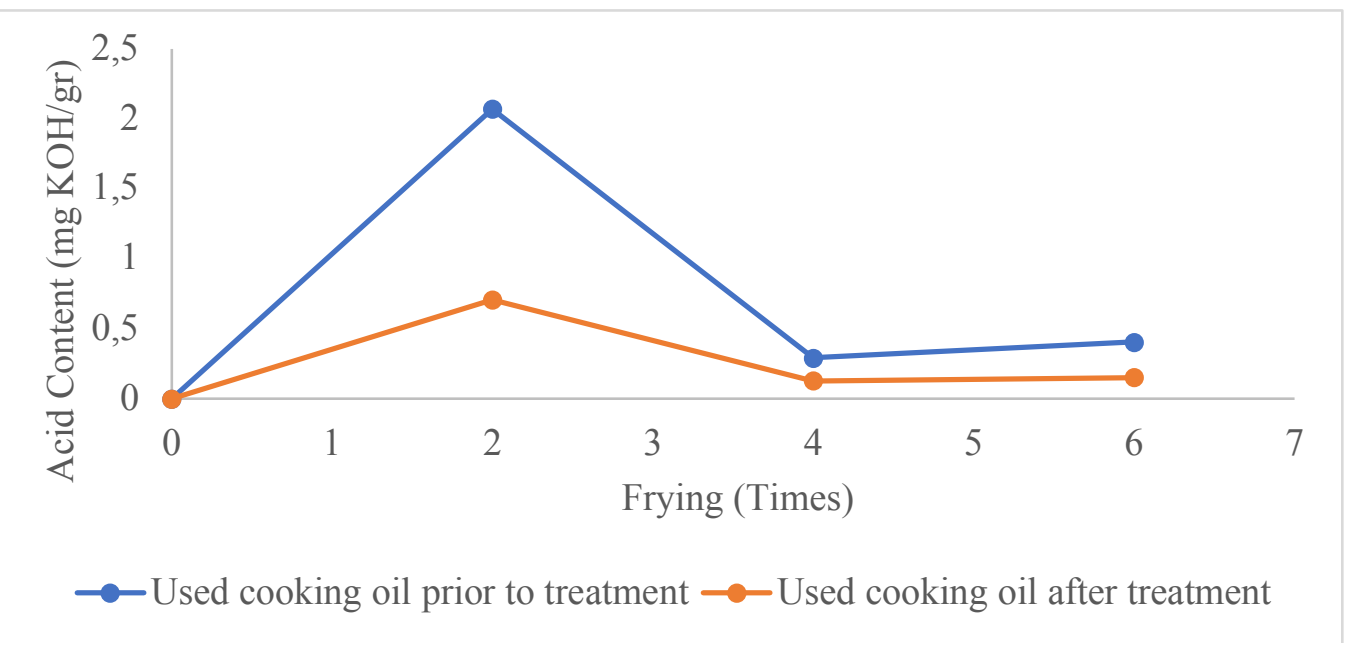

Figure 1. Graph comparison acid number used cooking oil prior to treatment and after treatment

The graph shows that activated carbon does lower acid number content in used cooking oil. The adsorption process by activated carbon involves three stages; compounds are absorbed on the outer walls of carbon, they penetrate through the pores, and are absorbed again by the inner walls of carbon, which results in a lower acid number. The reduction of acid number in used cooking oil from 2-time frying amounts to 0.7068 , from 4-time frying amounts to 0.1263 , and from 6-time frying amounts to 0.1515 as shown in Figure 2

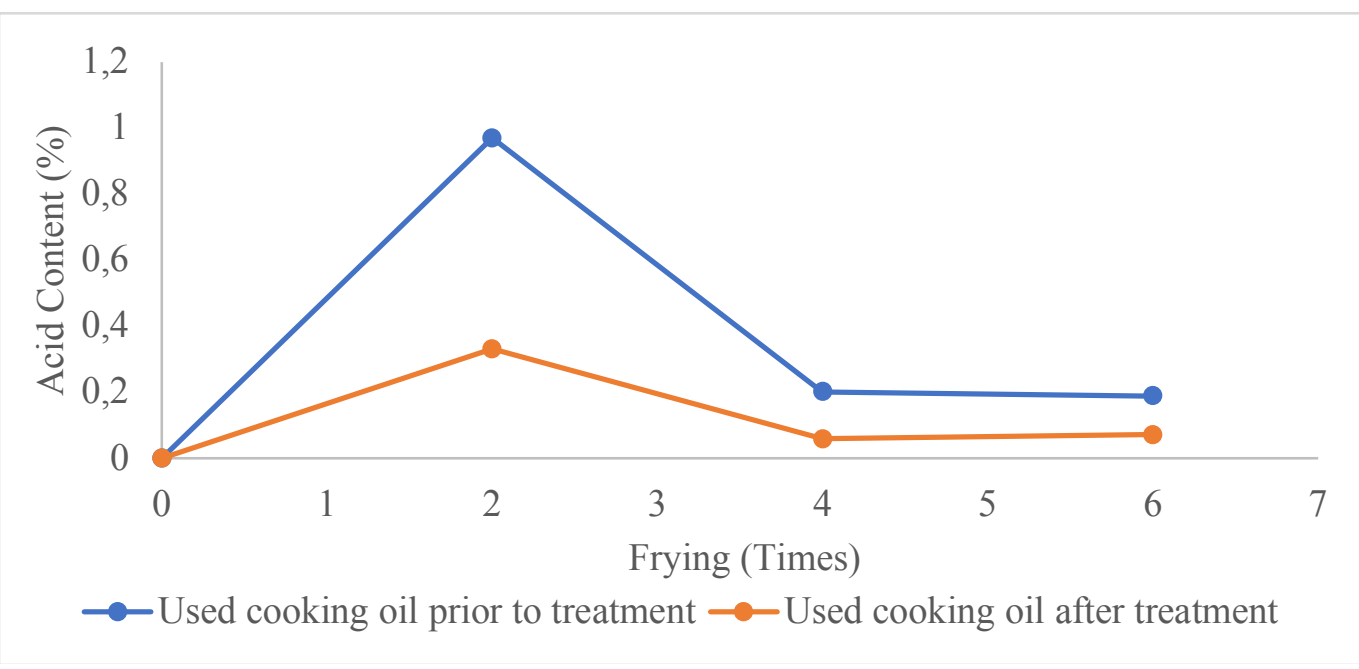

Figure 2. Graph comparison content acid used cooking oil prior to treatment and after treatment.

The graph shows that activated carbon does lower acid content in used cooking oil. Adsorption process by activated carbon involves three stages; compounds are absorbed on the outer walls of carbon, they penetrate through the pores, and are absorbed again by the inner walls of carbon, which results in lower acid content the use of activated carbon has been able to lower fat content by $0.3314 \%$ in 2-time frying cooking oil, which meets the purification quality standard. In the meantime, purification of 4 and 6-time frying cooking oil has lowered fat content by $0.0591 \%$ and $0.0710 \%$, respectively. The average reduction in acid level with the use of activated carbon is at $33.6819 \%$ (Figure 3) 


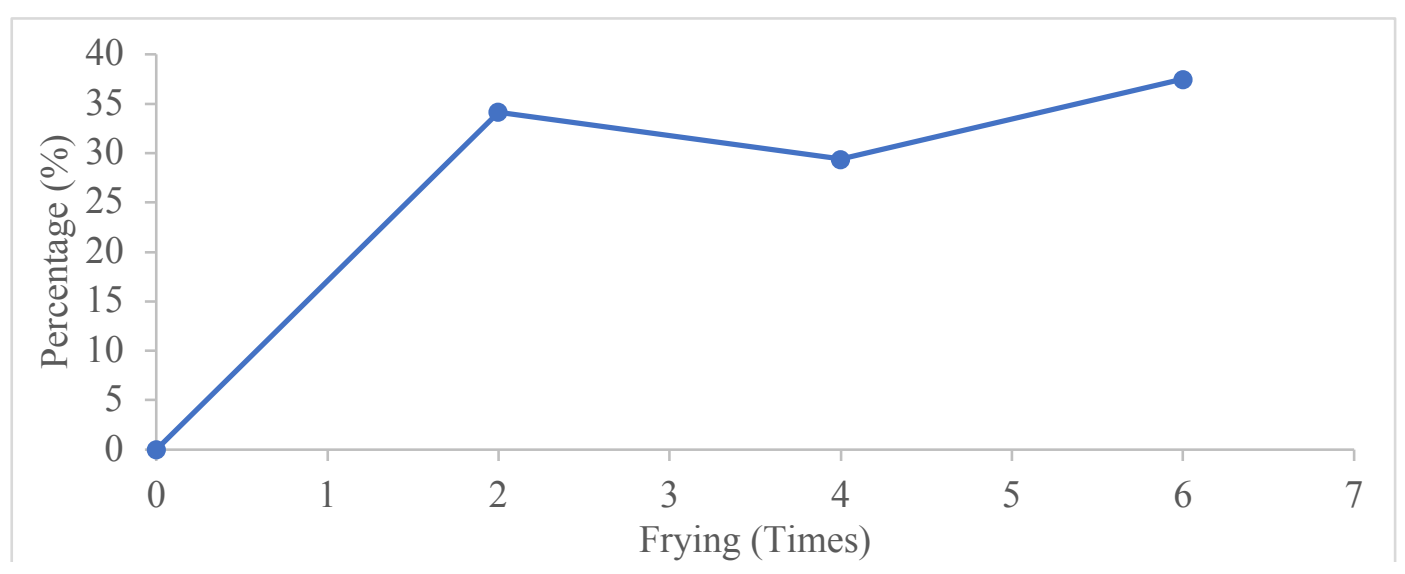

Figure 3. The percentage of free fatty acid

Moreover, stirring allows free fatty acid to be in more contact with activated carbon. These collisions facilitate more absorption on the walls and pores of activated carbon. The acid number in used cooking oil from the first frying is pretty high, at 2.00700, compared to that of the second and third frying. This is because the banana and tofu being fried contain more water than when banana and fritter, as well as banana and sweet potato, from the second and third frying respectively. The presence of water in oil results in hydrolysis. Other than that, food that contains more water also facilitates the growth of fungi. These fungi excrete certain enzymes that degrade triglycerides into free fatty acid and glycerol.

\section{b. Peroxide number}

Before the calculation of the peroxide number, each sample had to undergo paper titration. The average volume of $\mathrm{Na} 2 \mathrm{~S} 2 \mathrm{O} 3$ used for sample titration is given in the appendix. The amount of $\mathrm{Na} 2 \mathrm{~S} 2 \mathrm{O} 3$ average volume used for paper titration was $5 \mathrm{~mL}$ The results of peroxide number calculation of used cooking oil before and after treatment are given in the following Table 3.

TABLE III. Peroxide number (mg/gr) used cooking oil prior to treatment and after treatment

\begin{tabular}{lllll}
\hline Type of cooking oil & \multicolumn{4}{l}{ Time Frying } \\
\cline { 2 - 5 } & 0 & 2 & 4 & 6 \\
\hline Fresh cooking oil & 0.6827 & - & - & - \\
Used cooking oil prior to treatment & - & 4.6665 & 5.0408 & 5.1187 \\
& - & & & \\
Used cooking oil after treatment & - & 0.8734 & 1.1714 & 1.9352 \\
Peroxide reduction & - & 3.7931 & 4.3032 & 3.1862 \\
\% reduction of peroxide number & & 81.2836 & 85.3674 & 62.2462 \\
\hline
\end{tabular}

The peroxide number of sample cooking oil increased by 4.6665 for the 2-time frying, by 5.0408 for the 4-time frying, and by 5.1187 for the 6-time frying. This increase in peroxide number surpasses the maximum threshold of 2. After treatment, the peroxide number decreased by 3.7931 for the 2-time frying, by 4.0302 for the 4-time frying, and 3.1862 for the 6-time frying. The use of activated carbon has been able to lower peroxide number that meets the standard for cooking oil. Peroxide number of used cooking oil after treatment is decreased by 0.8734 for the 2-time frying, by 1.1714 for the 4-time frying, and by 1.9235 for the 6-time frying. The average decrease of peroxide number due to the use of activated carbon is by 76.2990 .

Peroxide number is often associated with the foul smell of cooking oil. Peroxide is a compound produced from oxidation due to contact with air and is accelerated by temperature and lighting. Analysis of peroxide number in fresh cooking oil used cooking oil, and purified cooking oil employs the iodometric method, in which an amount of oil is dissolved in an acetate solution made of chloroform that also contains KI, to allow for the release of iodine (I2). This released iodine are 
then titrated using sodium thiosulfate. The next step is adding an amylum indicator until the color blue is obtained. Further titration followed suit using sodium thiosulfate until the color blue is gone. The presence of blue color after the addition of amylum indicates the presence of iodine in the solution. The color blue is due to the spiral molecular structure of amylum that binds molecules. Calculation of peroxide numbers can be used to figure out the foul smell level of cooking oil. Earlier research using activated carbon made of Moringa oleifera successfully reduced peroxide number from 4.4 to 2.4 after purification. This proves that activated carbon is capable of lowering the peroxide number. Peroxide number in used cooking oil before and after treatment is given in the following Figure 4

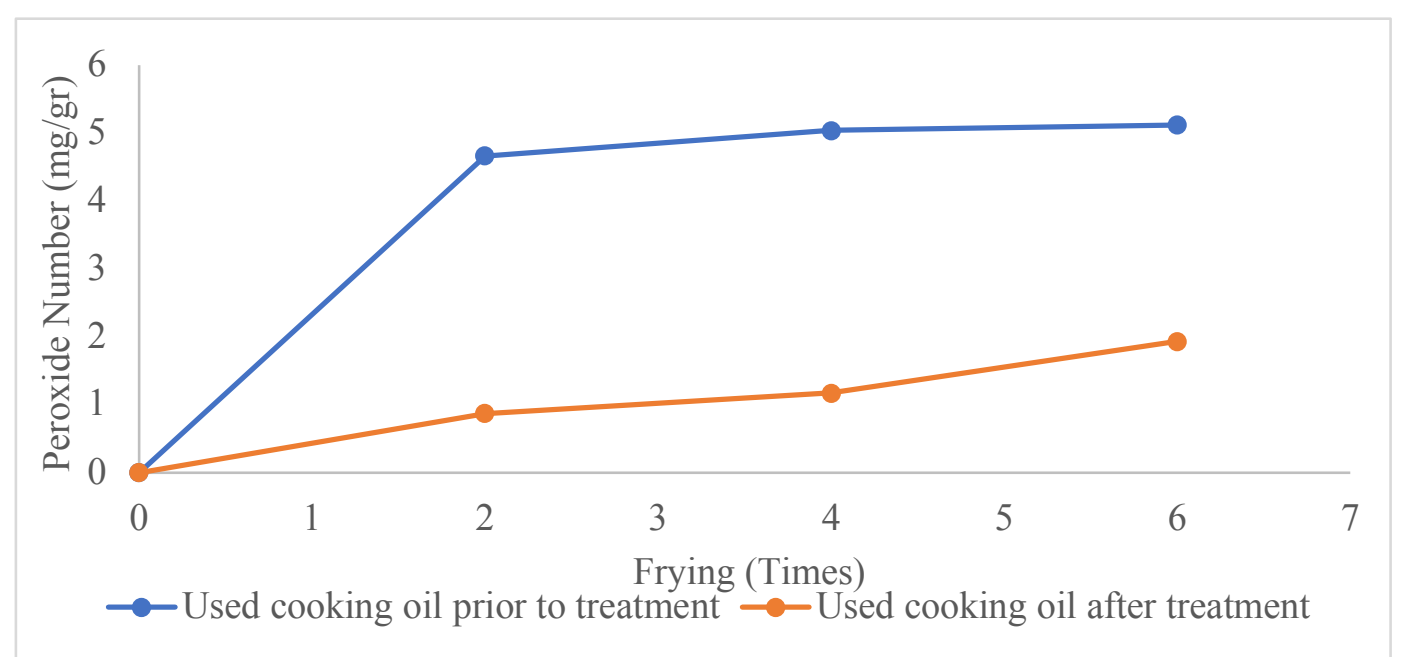

Figure 4. The resulted peroxide numbers

The graph above shows that activated charcoal able to reduce the peroxide number in liquefied cooking oil. The peroxide number refining for used cook oil after 2-times the frying has decreased from 4.6 to 0.8 , for 4-times the frying decreased 5.0 to 1.1 and for 6-times the frying has decreased 5.1 to 1,9 . Cooking oil is use other frequent the higher the value of the peroxide number. Therefore, a used cooking oil that again used repeated is actual dangerous for health (Figure 5).

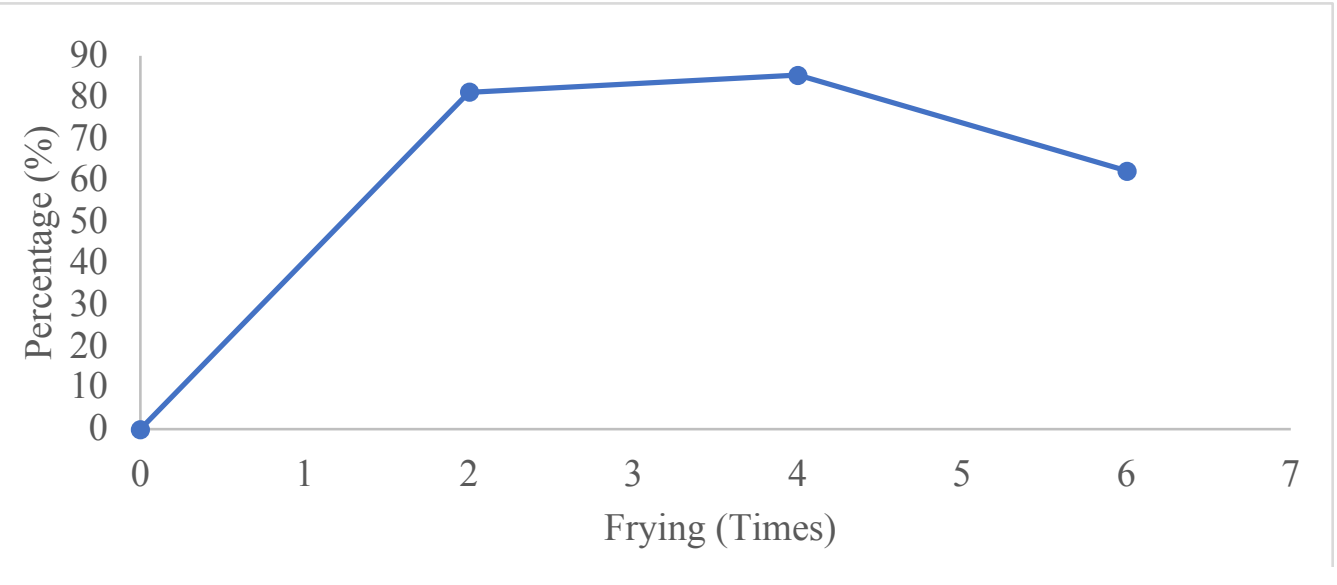

Figure 5. The percentage of lowering number peroxide

Adsorption of peroxide by activated carbon is possible due to potential difference between the surface of adsorbent and the solution, both by physical and chemical processes. 


\section{CONCLUISION}

The use of activated carbon lowers acid number by 0.7068 with a percentage of 34.1449 for the first frying, and by 0.1263 with a percentage of 29.4103 for the second frying. Meanwhile, the third frying results in acid number reduction by 0.1515 , with a percentage of 37.5092 . The use of activated carbon also lowers free fatty acid content by 0.3314 , with a percentage of 34.1508 for the first frying. The second frying shows a reduction by 0.0591 , with a percentage of 37.5066 . In the meantime, the peroxide number for the first frying is lower by 3.7391, with a percentage of 34.1508 . With the third frying results in peroxide number reduction by 3.1862 , with a percentage of 62.2462 .

\section{References}

[1] S. Keteren, Minyak dan Lemak Pangan, Jakarta: UI Press, 1986.

[2] R. Paputungan, S. Nikmatin and A. Madu, "Mikrostruktur Arang Aktif Batok Kelapa untuk Pemurnian Minyak Goreng Habis Pakai," Jurnal Keteknikan Pertanian, vol. 6, no. 1, pp. 69-74, 2018.

[3] S. Keteren, Minyak dan Lemak Pangan, Jakarta: UI Press, 1986.

[4] S. J. Alexander, Bailey Industries oil dan fat Product, New York London City: Jhon Wiley \& Sons, 1951.

[5] N. "Pemanfaatan Minyak Goreng Bekas dan Abu Kulit Buah Randu Sebagai Bahan Pembuatan Sabun Mandi Organik Berbasis Teknologi Ramah Lingkungan," Jurnal Teknologi Kimia dan Industri, vol. 2, no. 2, p. 27, 2013.

[6] A. "Pengaruh Suhu Interaksi Minyak Goreng Bekas Dengan Menggunakan Karbon Aktif Biji Kelor Terhadap Angka Iodin dan Angka Peroksida," UIN Maulana Malik Ibrahim, Malang, 2010.

[7] Z. Khoerunnisa, A. S. Wardana and R. Rauf, "Angka Asam dan Peroksida Minyak Jelantah Dari Penggorengan Lele Secara Berulang," Jurnal Kesehatan, vol. 12, no. 2, pp. 81-96, 2019.

[8] A. Rukmini, "Regenerasi Minyak Goreng Bekas dengan Arang Aktif Sekam Menekan Kerusakan Organ Tubuh," in Seminar Nasional Teknologi Universitas Widya Darma , Yogyakarta, 2007.

[9] F. Aryani, F. Mardiana and W. , "Aplikasi Metode Aktivasi Fisika dan Aktivasi Kimia pada Pembuatan Arang Aktif dari Tempurung Kelapa," Indonesian Journal of Laboratory, vol. 1, no. 2, pp. 16-20, 2019.

[10] W. "Optimasi Proses Adsorpsi Minyak Goreng Bekas dengan Adsorben Zeolit Alam," Teknik Kimia, Semarang, 2005.

[11] W. "Optimasi Proses Adsorpsi Minyak Goreng Bekas dengan Adsorben Zeolit Alam," Teknik Kimia, Semarang, 2005.

[12] A. Rukmini, "Regenerasi Minyak Goreng Bekas dengan Arang Aktif Sekam Menekan Kerusakan Organ Tubuh," in Seminar Nasional Teknologi Universitas Widya Darma, Yogyakarta, 2007.

[13] P. "Efektifitas Waktu Kontak Karbon Aktif Tempurung Kelapa Dalam Penurunan Kadar H2S Terlarut Pada Air Limbah Industri," Teknik Kimia, Semarang, 1996.

[14] R. Wijayanti, "Arang Aktif dari Ampas Tebu Sebagai Adsorben Pada Pemurnian Minyak Goreng Bekas," Kimia ITB, Bogor, 2009.

[15] S. Rohaju, Kerusakan Oksidasi Pada Makanan, Yogyakarta: Gajah Mada University Press, 2006.

[16] R. Wijayanti, "Arang Aktif dari Ampas Tebu Sebagai Adsorben Pada Pemurnian Minyak Goreng Bekas," Kimia ITB, Bogor, 2009.

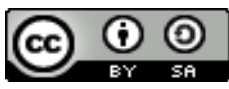

Jurnal IJCA is licensed under aÂ Creative Commons Attribution ShareAlike 4.0 